ISSN:1991-8178
EISSN: $2309-8414$
DOI: $10.22587 /$ ajbas.2017.11.15.11
Journal home page: www.ajbasweb.com

\title{
A Review about Olive Culture in Brazil
}

\author{
${ }^{1}$ Jéssica Maus da Silva, ${ }^{1}$ Ervandil Corrêa Costa
}

${ }^{1}$ Federal University of Santa Maria, Department of Forest Protection, Roraima Avenue, 1000, CEP 97105-900, Santa Maria (RS), Brazil.

Address For Correspondence:

Jéssica Maus da Silva, Federal University of Santa Maria, Department of Forest Protection, Roraima Avenue, 1000, CEP 97105-900, Santa Maria (RS), Brazil

E-mail: smausjessica@gmail.com

\section{ARTICLE INFO}

Article history:

Received 12 October 2017

Accepted 22 December 2017

Available online 31 December 2017

Keywords:

Olea europaea; cultive; pest insect; entomology.

\begin{abstract}
A B S T R A C T
Background: Olive culture is incipient in Brazil, what reinforces the need for data and research which subsidize the appropriate conditions regarding culture system, integrated pest management, harvesting and production methods. Economically, the increase of production is favourable to the country since the costs generated with imports can be reduced, thus promoting access to olive by-products for the national consumer. Objective: This work aimed to describe the economic importance as well as the main pests and diseases in olive orchards in Brazil. Results: The edaphoclimatic demands are key requirements to be considered when investing in olive trees; these plants need a cold season to ensure flowering. So far, the main pest insects described in the literature are Prays oleae, Palpita unionalis, Saissetia oleae and Bactrocera oleae. The disease Spilocaea oleagina is the most more frequent in cultures. Conclusions: Brazil has a productive potential for olive culture. However, it requires special care regarding orchard monitoring due to the incidence of pest insects and diseases. Brazilian products have been standing out, especially olive oil, which has a similar quality to their European counterparts.
\end{abstract}

\section{INTRODUCTION}

Olive trees (Olea europaea) are known for producing table olives and olive oil, however, their benefits go beyond these products. Since ancient times, the species is known for having medicinal properties, leaves are used for fighting against hypertension, atherosclerosis, diabetes, among others (Jänicke et al., 2003). The substances extracted from leaves are rich in polyphenols such as flavonoids (Pereira et al., 2007), which have antimicrobial activities (Korukluoglu et al., 2008). The by-products from residues of olive trees can also be used for food, cosmetics, and pharmaceuticals (Malik and Bradford, 2008).

Due to the increased consumption and the multiple purposes of olive trees, there has been the need to expand the cultivated area to supply this demand. The cultivated areas are distributed in several regions worldwide such as the Mediterranean Oriental Basin, Southeast Europe, West Asia, North Africa, North Iran, and South America. However, the Mediterranean region is the main producer, being responsible for $98 \%$ of the world's olive oil culture (Ryan and Robards, 1998).

In South America, the main producers and exporters of olives and olive oil are Argentina and Chile, with cultures of 70,000 and 20,000 hectares, respectively (Ricalde, 2013). In Brazil, olive culture is recent, and Rio Grande do Sul, Santa Catarina, Paraná, São Paulo and Minas Gerais have been investing in this culture (Villa and Oliveira, 2012).

Despite the fact that olive culture is considered an ancient technique, in Brazil there still are some obstacles to be envisaged regarding this. Thus, knowing the procedures to be implemented in culture areas such as seedling production, culture methods, caretaking, phytosanitary control, crop, among others, is an important tool to establish olive culture in Brazil.

\footnotetext{
Open Access Journal

Published BY AENSI Publication
}

(C) 2017 AENSI Publisher All rights reserved

This work is licensed under the Creative Commons Attribution International License (CC BY).

http://creativecommons.org/licenses/by/4.0/

\section{(c) (1) Open Access}

To Cite This Article: Jéssica Maus da Silva, Ervandil Corrêa Costa, A Review about Olive Culture in Brazil. Aust. J. Basic \& Appl. Sci., 11(15): 76-82, 2017 
Research related to olive is still incipient, and further research to help the scientific community to establish techniques aimed to developing its culture is still needed. There is a number of studies regarding this culture in Rio Grande do Sul, such as Edaphoclimatic Zoning (Wrege et al., 2009); Insects (Ricalde et al., 2015) and mites assemblies (Ricalde et al., 2012); Infestation index and biological aspects of Palpita forficifera Munroe, 1959 (Lepidotera: Pyralidae); and Spider assemblies in olive orchards (Ricalde, 2013).

From the development of olive orchards, as well as their productive potential in Brazil, this work has aimed to describe the economic importance and the main pest insects and diseases in olive orchards in the country.

\section{Olive (Olea europaea, Linnaeus, 1753):}

Olives (Olea europaea, Linnaeus, 1753) are originally from the Mediterranean region, where they have been cultivated since 10000 BC (Santos, 2002). This species belongs to the Oleaceae family, including the genera Fraxinus, Jasminum, Ligustrum, Phillyrea, Syringa, and Olea (Heywood, 1978). Olea europaea L. is the only species that produces edible fruits and adapts better to regions with tropical and temperate climates, reaching from four to eight meters high, remaining alive and productive for hundreds of years (Barranco et al., 2008).

Tree size is variable depending on how they are cultivated and the climate conditions, and other factors such as colour and size of leaves, wood colour, crown density, and characteristics of fruits have direct influence on the quality of the oil (Neto et al., 2008).

Olive leaves are perennial, have an elliptic-lanceolate shape and dark-green coloration in the adaxial side and silver in the abaxial side, remaining in branches from two to three years. They have an anatomical structure adapted to drought periods, are coriaceous with thick cuticle, and their stomates are situated in the abaxial side, providing protection to the plant against major water loss in environments of high evapotranspiration (Barranco et al., 2008).

Flowers are greenish white arranged into inflorescences, consisting of 10 to 40 flowers, which originate on the base of branch leaves produced the year before. Flowers have regular symmetry, consisting of four sepals where they form a calyx and four white or yellowish white petals that form the corolla, which has two stamens inserted in an opposite position and is formed by filament and a yellow anther (Oliveira and Abrahão, 2006; Barranco, 2008).

Olives are small ellipsoidal fruits which vary between 1,0 and 4,0 centimetres high, and 0,6 and 2,0 cm diameter, consisting of three fundamental tissues: endocarp (kernel), mesocarp (pulp), and exocarp (epidermis) (Oliveira, 2011).

\section{History in Brazil:}

The olive culture was introduced in Brazil in 1800 by religionists, being later cultivated by farmers who obtained good results in their production, but were ordered by royal decree to destroy their orchards for their products not to compete with the Portuguese products (Ricalde, 2013). In Rio Grande do Sul, it was introduced in 1948, with an incentive from the Department of Agriculture, which encouraged producers through awards and territorial tax exemption. However, due to the lack of technical basis, orchards resulted in low quality products, leading to the lack of interest for the culture (Coutinho et al., 2009).

By the end of the 1960s, some commercially planted areas started to emerge in Brazil. The municipality of Uruguaiana, in Rio Grande do Sul, was one of the pioneers in olive culture, where approximately 72,000 seedlings were planted in a farm, and the final by-products (olive oil and table olives) were analyzed in Brazilian and Italian laboratories, where they concluded that the quality of the Brazilian products was similar to the Italian products. From these analysis, the commercially planted areas started to spread within the state (Coutinho et al., 2009).

From 2000, there has been an increase in studies about agro-climatic and economic zoning by offices linked to the Ministry of Agriculture, where they established the Brazilian regions with adequate characteristics for large scale olive culture (Mello and Pinheiro, 2012). In Brazil, olive culture is more frequent in the South and Southeast regions, in Minas Gerais, Rio de Janeiro, São Paulo, Paraná, Santa Catarina and Rio Grande do Sul (Coutinho et al., 2009).

According to Vieira et al. (2010), in recent years olive trees have been introduced mainly in some specific areas in Minas Gerais, São Paulo and Rio Grande do Sul, with an estimation to expand the initial planted area in approximately $50 \%$.

\section{Economic importance:}

Brazil is one of the largest importers of olive derivatives, exceeded only by the United States and European countries (Coutinho et al., 2015). Argentina, Spain and Portugal are the main countries which offer olive derivatives for Brazil (Aued-Pimentel et al., 2002).

It is estimated that olive cultures cover approximately 1,200 hectares between Rio Grande do Sul, Minas Gerais and São Paulo, with the perspective of growth in the production due to the development of financing 
projects that aim to promote olive culture in Rio Grande do Sul, which can reach around 100 hectares each (Alba et al., 2013).

According to statistics obtained by the International Olive Council - IOC, Brazil is the second major world importer of table olives and third of olive oil. In the 2015/2016 crop, the country imported the equivalent to 102,000 tons of table olives and 50,000 tons of olive oil, with the United States coming first for both products, and Japan second in olive oil imports (Consejo Internacional Oleícola, 2016).

The causes that influence the increasing demand for olive by-products can be linked to the increased purchasing power of some social classes, together with more affordable prices of products in the Brazilian market, followed by the promotion of the benefits of olive oil consumption for health (Mello and Pinheiro, 2012). Due to these questions, research has been developed which aims to economically enable olive planting and allow Brazil to become a producer in this market, generating income and employment for the sector, and reducing costs with imports (Vieira et al., 2010).

Rio Grande do Sul and Minas Gerais have recently become the largest olive by-products producers (Wrege et al., 2015). However, as the planting areas are small, the production is still insignificant to meet the demands of the country's internal market, thus making it necessary to import from Europe and South America (Wrege et al., 2009).

\section{Edaphoclimatic demands:}

Olives are normally cultivated in Mediterranean semiarid regions, characterized by high temperatures and low rainfall rates in the dry months (Coutinho et al., 2009; Wrege et al., 2009; Alba et al., 2013). Climate is a limiting factor for the development of flowers, pollination, fixation, and maturation of fruits, and influences on the quality of olive oil and table olives (Wrege et al., 2015).

The growth of olives is slow, when the temperature is lower than $12.5^{\circ} \mathrm{C}$ and the plant is dormant, since cold accumulation is necessary for reproduction (Oliveira, 2012). Regarding fruitification, the ideal temperature varies between $25^{\circ} \mathrm{C}$ and $35^{\circ} \mathrm{C}$, nevertheless, olive trees can endure temperatures as high as $40^{\circ} \mathrm{C}$, without the branches and leaves being burnt (Coutinho et al., 2009).

Studies performed by Alba et al. (2013) have reported that Rio Grande do Sul meets the climatic demands for olive culture, since temperatures rarely go beyond $35^{\circ} \mathrm{C}$, except for atypical years, when the temperature rarely goes beyond $40^{\circ} \mathrm{C}$ in Summer. In the southern half of the state, the climate for fruit maturation is considered ideal, with temperatures varying between $25^{\circ} \mathrm{C}$ and $35^{\circ} \mathrm{C}$. In Winter, the temperature varies between $3^{\circ} \mathrm{C}$ and $15^{\circ} \mathrm{C}$, hardly going below $0^{\circ} \mathrm{C}$, what is also considered optimal for the development of olive trees.

In Chile, when Winters are hot, mainly in years when the climatic phenomenon El Niño occurs, the subsequent production is reduced, indicating that the species demands a period of intense cold to keep flowerings abundant (Alba et al., 2013).

The mean annual hydric demand oscillates between 650 and $800 \mathrm{~mm}$, with preferably regular rainfall (Coutinho et al., 2009; Wrege et al., 2009; Alba et al., 2013). In the case of dry seasons, olive trees induce the production of male flowers, as a survival measure. Roots reach great depths to capture moisture, and horizontally near the surface, they develop in such a way that they interlace with the roots of neighbouring plants, even in wide spaces (10 m x $10 \mathrm{~m}$ ) (Alba et al., 2013).

The elevated relative air humidity favours the occurrence of phytosanitary problems, especially diseases caused by fungi. The occurrence of haze is harmful for olive trees, mainly during the flowering period, and can lead to the total fall of leaves (Alba et al., 2013).

Sandy and well-drained soils are preferable for the culture of olives (Guerrero, 2014). Average texture soils (loamy, sandy loam, clayish loam) adapt better to the culture, considering that root growth is superficial, soils with effective depth between 0.50 and $1.20 \mathrm{~m}$ are recommended provided that they do not show limitations such as elevated water table, high aluminium levels, among others. Also, acid ( $\mathrm{pH}$ lower than 5,5) and saline soils with high levels of interchangeable aluminium as well as high concentrations of chloride, boron, and free calcium carbonate should be avoided (Coutinho et al., 2015).

\section{Olive plant health:}

Maintaining plants healthy, free from pests and diseases contributes for the improvement of quality of fruits and increase in production, and according to Haniotakis (2005), around 30\% of decrease in production of an olive orchard is related with the attack of insects, diseases, and weed, where $15 \%$ is associated only with insects, with control costs that can reach 100 million euros a year.

Olive cultures are usually attacked by several arthropods (Prado and Silva, 2006). However, the ones that cause economic damage in European countries are the black scale (Saissetia oleae, Oliver, 1791) (Hemiptera: Coccidae); olive moth (Prays oleae, Bernard, 1788) (Lepdoptera: Plutellidae); olive fruit fly (Bactrocera oleae, Rossi, 1790) (Diptera: Tephritidae); and olive bark beetle (Pholeotribus scarabaeoides, Bern, 1788) (Coleoptera: Scolytidae) (Barranco et al., 2008; Cavaco et al., 2006). In Brazil, mainly in Rio Grande do Sul, 
the main pests are black scale (S. oleae) and olive leaf moth (Palpita unionalis Hubner, 1796) (Lepdoptera: Pyralidae) (Coutinho et al., 2009).

In addition to pest insects, there are some biotic diseases which are either caused by fungi, bacteria and viruses or by abiotic diseases inflicted by nutritional deficiencies or climatic factors such as drought, frost, and periods of excessive rainfall (Pereira et al., 2006).

\section{Gafa (Colletotrichum acutatum; Colletotrichum gloesporioides):}

Gafa is a disease caused by the fungi Colletotrichum, C. acutatum and C. gloesporioides (Mendes and Cavaco, 2009), usually occurring in fruits and rarely in leaves and branches (Cabanas and Pavão, 2009). Also, according to authors, the characteristic symptom of this disease is putrefaction and mummification of fruits, where olives start to show round brownish spots, what decreases the fruit pulp volume.

Its development is directly related to atmospheric humidity, because sporulation needs a relative air humidity of about $90 \%$ (Cabanas and Pavão, 2009). The main loss of this disease is the decrease of fruit quality (Ferraz, 2012).

Amongst prevention measures, it can be cited the adequate pruning, early harvest, and the use of herbicides registered for the integrated protection of olive trees (Cabanas and Pavão, 2009).

\section{Spilocaea oleagina:}

This disease is considered one of the most relevant for olive cultures, and the favourable conditions for the development of this pathogen are dense planting, poor aeration, and excess moisture (Coutinho et al., 2015). The characteristic symptom is the presence of round spots of variable sizes and a coloration that varies from dark-brown to black in leaves, or in fruit peduncles, though in a lower frequency (Rodrigues and Correia, 2009).

The beginning of Spring and Autumn are the most favourable periods for disease infection and development due to temperature and relative air humidity, which create the conditions for the development of the pathogen (Rodrigues and Correia, 2009). The shedding and debilitation of the plant render a low productivity, being this the main loss caused by this disease (Coutinho et al, 2015).

To prevent this disease, some cupric fungicides are indicated, such as copper hydroxide, copper oxychloride, and cuprous oxide. The application must be performed before the first autumnal rainfall, and the crown must be wet for all the plant organs to remain protected (Mendes and Cavaco, 2009).

\section{Tuberculosis (Bacterium savastanioi):}

Bacterium savastanioi is commonly known by names such as olive galls, tuberculosis or tumours. This disease is disseminated through rain water, relative humidity higher than $80 \%$, wind, animals, and even man, when using contaminated material and infected vegetative propagation material (Mendes and Cavaco, 2009). The characteristic symptoms are the occurrence of round-shaped galls of different sizes, generally found in the trunk, branches and buds (Coutinho et al., 2015).

Infections occur during Summer when rainfall is abundant (Barranco, 2008); it is important to highlight, however, that the bacteria can survive in galls from one season to another (Mendes and Cavaco, 2009). According to the author cited previously, the occurrence of this disease in olive trees leads to the weakening of branches where the galls are, what can influence on the productivity of trees, especially the younger ones, when high infections occur, leading them to death.

Amongst the control measures, it is necessary to be aware of preventative measures being the main one the elimination of infected vegetable tissues during pruning (Makilutila, 2017).

\section{Olive moth (Prays oleae):}

Prays oleae (Bernard, 1788) (Lepdoptera: Praydidae) is one of the main pest insects of olive cultures (Lopes et al., 2010). The insect causes injuries to leaves, flowers and fruits, yet it is in the fruits where the major damage occurs (Barranco et al., 2008). Larvae attack fruits in initial development causing them to fall (Ramalheiro, 2009).

The damage caused by the insect can be classified into direct, affecting the production, or indirect, damaging the quality of olive oil or table olives (Mendes and Cavaco, 2009). The introduction of plants which produce pollen or nectar for natural enemies is an alternative of biological control, since natural enemies feed themselves from the eggs of $P$. oleae larvae (Nave et al., 2016). Chemical control can be achieved with insecticides such as deltamethrin and dimethoate (Mehri et al., 2006).

\section{Margaronia or olive leaf moth (Palpita unionalis):}

Palpita unionalis (Lepidoptera: Pyralidae) is known as olive bud worm (Coutinho et al., 2015) or olive leaf moth (Yilmaz and Genç, 2012). Also, according to the author, the species is considered a primary pest in nurseries or orchards of olive. 
Females oviposit in buds, and when larvae emerge, they feed from these blooms. The damage caused is the reduction of the foliar area and, consequently, a low yield in the following year's production, since olives fruit in these blooms. Lays usually start in November, thus the period of the largest occurrence of attacks is March (Estay et al., 2009).

According to Coutinho et al. (2015), hot and humid climates favour the development of insects. When the climatic phenomenon El Niño occurs, these insect populations increase. Alternatives such as installing light traps, removing vigorous new branches (thieves), maintaining the crown free from weeds, and applying Bacillus thurigiensis are procedures that help establish the control of this pest insect.

\section{Black scale (Saissetia oleae):}

Black scale Saissetia oleae (Olivier) (Hemiptera: Coccidae) is one of the most frequent pest species in olive cultures, and it is widely distributed in Brazil (Prado and Silva, 2006). The main damage caused by this pest is the suction of sap in various plant organs, thus damaging tree development. Another damage caused by this insect is the reduction of the photosynthetic area and fruit production, since the excrements eliminated by black scales favour the development of sooty mold (Noguera et al., 2003). The occurrence of this species can be observed in different plant organs such as branches, twigs, and leaves (Soares et al., 2012).

Shaded trees, with dense foliage and in environments with high relative air humidity favour the development of black scales as well as the excessive use of fertilizers, what leas to an increase in the amount of leaves (Prado and Silva, 2006). To control this pest, a treatment with mineral oil must be carried out, aiming to impermeabilize the leaves, preventing the insects from feeding from the sap. This treatment has a positive effect, nevertheless it does not establish a satisfactory control of black scales (Rodrigues and Childers, 2002).

\section{Olive fruit fly (Bactrocera oleae):}

Bactrocera oleae (Gmelin) (Diptera: Tephritidae) is considered one of the main pest species in olive cultures due to the damages they can cause (Gonçalves and Andrade, 2010; Gonçalves and Andrade, 2012). The female performs oviposition on the fruit surface, what results in premature fall of olives, decrease in production, quality and economic value of olive oil, in addition to the development of larvae inside the fruits, leading to the increase of acidity of olive oil (Neuenschander and Michelakis, 1978). In case the final product is table olives, a single sting of this insect will cut their whole commercial value (Ferraz, 2012).

Coastal areas are the most susceptible to the development of olive fruit flies, considering that temperature and relative air humidity are favourable for their growth (Ramalheiro, 2009). According to Sobreiro (1992), cultures such as Galega, Picual and Maçanilha are susceptible to the attack of B. oleae, whereas the cultures Negrinha, Galega Grada de Serpa, Azeiteira, and Verdeal Alentejana are more resistant. It is important to highlight that this pest insect has not been recorded in Rio Grande do Sul so far.

\section{Conclusion:}

Brazil has a productive potential for olive culture, however, due to the high implementation costs, the cultivated area is restricted, consequently leading to the insufficient production to supply the internal market.

The culture of olives is demanding, thus monitoring the incidence of pest insects and diseases is essential to ensure the production as well as quality products, since the acidity of olive oil is often related to the incidence of pests in orchards.

The quality of aggregated value to the Brazilian products has been increasing due their similarity with products of European origin.

\section{REFERENCES}

Alba, J.M.F., C.A. Flores, M.S. Wrege, 2013. Zoneamento Edafoclimático da Olivicultura para o Rio Grande do Sul. Brasília, 1 ed.

Aued-Pimentel, S., E. Takemoto, R.S. Minazzi-Rodrigues, E.S.G. Badolato, 2002. Azeite de oliva: incidência de adulterações entre os anos de 1993 a 2000. Revista Instituto Adolfo Lutz, São Paulo, 61(2): 69-75.

Barranco, D., R. Fernández-Escobar, L. Rallo, 2008. El cultivo del olivo. Madrid, 6 ed.

Cabanas, J.E., F. Pavão, 2009. Pragas e Doenças do olival. In: RODRIGUES, M.A., C.M. CORREIA (Eds.), Manual de safra e contra safra do olival. Bragança: Instituto Politécnico de Bragança.

Cavaco, M., R. Sismeiro, M. Guerra, 2006. Serviço Nacional de Avisos Agrícolas. Métodos de previsão e evolução dos inimigos das culturas. Olival. Ministério da Agricultura, do Desenvolvimento Rural e das Pescas de Portugal.

Consejo Oleícola Internacional (COI), 2016, Madrid. Retrieved from http://www.internationaloliveoil.org/estaticos/view/132-world-table-olive-figures on 05st May. 2017. 
Coutinho, E. F., F.C. Ribeiro, T.H. Cappellaro, 2009. Cultivo de oliveira (Olea europaea L.): Clima. Pelotas, RS. Retrieved from https://www.infoteca.cnptia.embrapa.br/bitstream/doc/783494/1/sistema16.pdf on 01st Agust 2017.

Coutinho, E. F., R.O. Jorge, J.A. Haerter, V.B. Costa, 2015. Oliveira: Aspectos técnicos e cultivos no Sul do Brasil. Brasília, 1 ed.

Estay, P.P., V.F. González, C.B. Rojas, 2009. Plagas del Olivo y su Manejo em el Valle de Azapa. Informativo Oficina Técnica INIA URURI, 9: 1-6.

Ferraz, M.M.P.F., 2012. Contribuição para o estudo do tratamento de efluentes de lagares de azeite. Dissertação (Mestrado Engenharia do Ambiente) - Universidade Nova de Lisboa, Lisboa.

Gonçalves, M.A., L. Andrade, 2010. Entomofauna associadas à cultura da oliveira no sul de Portugal. XIV Congresso Ibérico de Entomologia. Lugo, Espanha.

Gonçalves, M.A., L. Andrade, 2012. Entomofauna associated with the olive tree in southern Portugal. IOBC wprs Bulletin, Athens, 79: 91-99.

Guerrero, J.J.L., 2014. Enfermedades del Olivo em la província de Jaén: organismos fitopatógenos. Trabajo Fin de Grado. Universidad de Jaén, Facultad de Ciencias Experimentales, Jaén.

Haniotakis, E.G., 2005. Olive pest control: present status and prospects. IOBC wprs Bulletin, Athens, 28(9): $1-9$.

Heywood, H.U., 1978. Flowering Plants of the World. Oxford University Press, London.

Jänicke, C., J. Grünwald, T. Brendler, 2003. Handbuch Phytotherapie. Wissenschaftliche Verlagsgesellschaft, Stuttgart.

Korukluoglu, M., Y. Sahan, A. Yigit, 2008. Antifungal properties of olive leaf extracts and their phenolic compounds. Journal of food safety, 28(1): 76-87.

Lopes, D.J.H, R. Pimentel, N. Macedo, J.T. Martins, M. Zorman, L.B. Ventura, M.H. Aguiar, J. Mumford, A.M.M. Mexia, 2010. Pest thet affect the olive groves on Terceira is land, Azores. IOBC wprs Bulletin, 59: 3946.

Makilutila, M., 2017. Efeito da gestão do solo no estado nutricional e produtividade das árvores em olival. Dissertação (Mestrado Agricultura Tropical) - Instituto Politécnico de Bragança, Bragança, Portugal.

Malik, N.S.A., J.M. Bradford, 2008. Recovery and stability of oleuropein and other phenolic compounds during extraction and processing of olive (Olea europaea) leaves. J. Food Agric. Environ. 6: 8-13.

Mehri, H., M. R. Mehri-Kamoun, D. A. Bem, M. Mahjoub, 2006. The effect of bactospeine and three insecticides on olive pollen germination and tube growth. Adv. Hortic. Sci., 20: 140-146.

Mello, L.D., M.F. Pinheiro, 2012. Aspectos de azeites de oliva e de folhas de oliveira. Alimentos e Nutrição, Araraquara, 23(4): 537-548.

Mendes, F., M. Cavaco, 2009. Manual de proteção fitossanitária para proteccção integrada e agricultura biológica do Olival. Lisboa.

Nave, A., F. Gonçalves, A.L. Crespí, M. Campos, L. Torres, 2016. Evaluation of native plant flower characteristisc for conservation biological control of Prays oleae. Bulletin of Entomological Research, 106(2): 249-257.

Neto, J.V., A.F. Oliveira, N.C. Oliveira, H.S.S Duarte, E.D. Gonçalves, 2008. Aspectos técnicos da cultura da Oliveira. EPAMIG, Belo Horizonte.

Neuenschwander P, S. Michelakis, 1978. Infestation of Dacus oleae (Gmel.) (Diptera, Tephritidae) at harvest time and its influence on yield and quality of olive oil in Crete. J. Appl. Entomol., 86: 420-33.

Noguera, V., M.J. Verdú, A. Gómez-Cadenas, J.A. Jacas, 2003. Ciclo biológico, dinámica poblacional y enemigos naturales de Saissetia oleae Olivier (Homoptera: Coccidae), en olivares del Alto Palencia (Castellón). Boletín de Sanidad Vegetal Plagas, 29(4): 495-504.

Oliveira, A.F., E. Abrahão, 2006. Botânica e morfologia da oliveira. Informe Agropecuário, Belo Horizonte, 27(231): 13-17.

Oliveira, M.C., 2011. Abacateiro e Oliveira como fontes de matéria-prima visando a extração de óleo. Tese (Doutorado Agronomia/Fitotecnia) - Universidade Federal de Lavras, Lavras, MG.

Oliveira, M.C., J.D. Ramos, R. Rafael Pio, M.G. Cardoso, 2012. Características fenológicas e físicas e perfil de ácidos graxos em oliveiras no sul de Minas Gerais. Pesquisa Agropecuária Brasileira, Brasília, 47(1): 30-35.

Pereira, A.P., I.C.F.R. Ferreira, F. Marcelino, P. Valentão, P.B. Andrade, R. Seabra, L. Estevinho, A. Bento, J.A. Pereira, 2007. Phenolic compounds and antimicrobial activity of olive (Olea Europaea L. Cv. Cobrançosa) leaves. Molecules, 12(5): 1153-1162.

Pereira, L.V., A.F. Oliveira, L.V. Carvalho, P.E. Souza, 2006. Principais doenças da oliveira: descrição e danos. Informe Agropecuário, Belo Horizonte, 27(231): 73-78.

Prado, E., R.A. Silva, 2006. Principais praga da Oliveira: Biologia e Manejo. Informe Agropecuário, Belo Horizonte, 27(231): 79-83. 
Ramalheiro, J.P.S.C., 2009. Contribuição para a caracterização bioquímica do estado de maturação de azeitonas de diferentes variedades. Dissertação (Mestrado em Engenharia Alimentar - Qualidade e Segurança Alimentar) - Universidade Técnica de Lisboa, Lisboa.

Ricalde, M.P., 2013. Artropodofauna associada à cultura da oliveira (Olea europaeae L.) no Rio Grande do Sul, Brasil. Tese (Doutorado em Fitossanidade) - Universidade Federal de Pelotas, Pelotas, RS.

Ricalde, M.P., D.E. Nava, A.E. Loeck, E.F. Coutinho, A. Bisognin, F.R.M. Garcia, 2015. Insects related to olive culture in Rio Grande do Sul State, Brazil. Ciência Rural, 45(12): 2125-2130.

Ricalde, M.P., F.R.M. Garcia, D.E. Nava, A.E. Loeck, M.G. Donatti-Ricalde, E.F. Coutinho, 2012. Oxicenus maxwelli (Keifer) (Acari: Eriophyidae) damaging olive tree, Olea europaea L., in Rio Grande do Sul State. Ciência Rural, 42(5): 767-769.

Rodrigues, J.C.V., C.C. Childers, 2002. Óleos no manejo de pragas e doenças em citros. Revista Laranja, 23(1): 77-100.

Ryan, D., K. Robards, 1998. Critical Review. Phenolic compounds in olives. Analyst, 123(5): 31R-44R.

Soares, M.A., M.D.C.M. Da Cruz, L.M. Martins, R.P. De Carvalho, E.M. Pires, V.G.M. De Sá, 2013. Ocorrência da Cochonilha Negra Saissetia oleae (Olivier) (Hemiptera: Coccidae) em Oliveiras Olea europaea L. (Oleaceae) cv. Ascolano em Diamantina, Minas Gerais, Brasil. EntomoBrasilis, 6(3): 242-244.

Sobreiro, J.B., 1992. Guia para a proteção fitossanitária da oliveira. M. M IPPAA - CNPPA, 55 p.

Vieira, L.G.C., M.D.F.B. Piccolo, A.F. De Oliveira, J.D.A.P. Ribeiro, W.C. De Abreu, F.P. De Araujo, M.A.P. Cardoso, 2010. Características físico-químicas e perfil de ácidos graxos de azeites obtidos de diferentes variedades de oliveiras introduzidas no Sul de Minas Gerais-Brasil. Semina: Ciências Agrárias, Londrina, 31(1): 127-136.

Villa, F., A.F. Oliveira, 2012. Origem e expansão da oliveira na América Latina. In: Oliveira, A.F. de. et al. Oliveira no Brasil: tecnologias de produção. Epamig.

Wrege, M.S., E.F. Coutinho, A.P. Pantano, R.O. Jorge, 2015. Distribuição Potencial de Oliveiras no Brasil e no Mundo. Revista Brasileira de Fruticultura, Jaboticabal, 37(3): 656-666.

Wrege, M.S., E.F. Coutinho, S. Steinmetz, C. Reisser Junior, I.R. Almeida, R. Matzenauer, B. Radin, 2009. Zoneamento agroclimático para oliveira no estado do Rio Grande do Sul. Pelotas, RS. 24 p. Retrieved from https://www.embrapa.br/busca-de-publicacoes/-/publicacao/747040/zoneamento-agroclimatico-para-oliveirano-estado-do-rio-grande-do-sul on 01st August. 2017.

Yilmaz, Ç., H. Genç, 2012. Determination of the life cycle of the olive fruit leaf moth, Palpita unionalis (Lepidoptera: Pyralidae) in the laboratory. Florida Entomologist, 95(1): 162-170. 